\title{
Designing and Implementing an Organoleptic Test Application for Food Products Using Android Based Decision Tree Algorithm
}

\author{
https://doi.org/10.3991/ijim.v13i10.9669 \\ Radius Tanone ${ }^{(凶)}$, Hendra Budi Prasetya \\ Universitas Kristen Satya Wacana, Salatiga, Indonesia \\ radius.tanoneduksw. edu
}

\begin{abstract}
The development of food and beverage products increases over the years. The high level of food consumption led to the presence of new food and beverage brands produced in Salatiga. In accordance with this fact, Organoleptic Tests or in other words evaluation of food products could be conducted well if the obtained dataset had a complete, rapid, and accurate information. The required information could be clarified into the dataset that was used to calculate the testing. Manually calculating the process was a problem that usually appeared. As a result, losing or having a broken report on the organoleptic test often occurred. Mileage of the research setting became another problem that appeared when the research conducted out of the town, Salatiga. A combination of R\&D method and application of algorithm was implemented in this research by using the performed stages. These stages started from the identification of problems to the testing of the systems. During the process of organoleptic testing, Weka 3.8.2 was used as a tool to test the C4.5 algorithm and an implementation of the applied algorithm on the android. The results of this study revealed that the average classification accuracy of the J48 algorithm in Weka could achieve above $90 \%$ accuracy and average score of hedonic scaling system was in "agree" category. It also showed that the algorithm and the testing of the systems which implemented on android has a credible performance in classifying data.
\end{abstract}

Keywords - Organoleptic test, decision tree, C4.5 algorithm, android

\section{Introduction}

Organoleptic test or in other words senses or sensory evaluation is a testing procedure which done by utilizing the five senses of human to evaluate the texture, color, aroma, and flavor of food, beverage, and/or drug products. This test has an essential role to the product development. Sensory evaluation is conducted to assess the desired changes on certain product or the ingredients, identify the area in the interest of product development, evaluate the competitors' products, observe the changes during the process and the conservation, and provide the data which is required to promote the product [1]. 
Particularly, manual calculation on the process of organoleptic test is the frequent problem occurs which result in losing or having broken report on the tested objects. Additionally, calculating manually the data of the test requires a lot of time. Another problem arises is concerning the mileage of the research setting when the research conducted out of Salatiga. Thereafter, with regard to the problems, Decision Tree appears. Decision Tree is well-known and proved to be powerful as a classification and prediction method. This method aims to change facts into a decision tree which presents understandable rules in natural language. The process of applying decision tree method starts from the root node to the leaves node. This happens recursively which each branch explains the conditions and each tip of the tree claims the decisions [2].

Therefore, given the importance of the organoleptic test problems, this study specifically aimed to investigate on how to assist researchers in conducting the organoleptic test by decision tree based on Android operating system. In addition, the primary purpose of this study was generally to assist researchers in order to discover the process of organoleptic test through a hedonic scale which was assessed by panelist. This study could also provide advantages for researchers be able to have an easily reachable research setting and saving time when conducting the test out of the town. The scope of the research problem in developing the application system of organoleptic test or hedonic evaluation was that the system was designed on Android by using Android Studio. Thus, an Android application was created to discover the hedonic scale of a food product by using decision tree and organoleptic test by calculating 1-7 scales of aroma and flavor in a food and beverage product.

\section{Literature Review}

Sartika and Sensure (2017) explained that data mining was an analysis process towards a group of data in the database which helped to obtain information that will be used in the following phases. They also argued that classification was the commonly used technique in data mining process. It was known as a data mining modeling technique that requires unclassified data to be applied in classifying new data [3].

A study conducted by Tarwendah (2017) showed that increased activities and job demands made Indonesian prefer to consume finished food products. Additionally, she stated that Indonesian consumption level on finished food and beverage products rose over years. As a result, various food and beverages companies in Indonesia were increasingly producing new products. Consequently, one that need to be considered was the level of consumer awareness of a brand. To put it simply, Tarwendah (2017) considered brand awareness as a key to find out whether the products which produced by a company could have a well sales position and survive in the market. Also, it could evaluate the products quality in order to meet the consumers' expectations. More importantly, in terms of products' taste, comparison study of sensory attributes and hedonic evaluation was conducted based on the similar reputable products in the market [4].

Another study by Widayu (2017) revealed that in the business field, data mining technique was applied to support the wide range of business intelligent applications 
such as customer profiling, targeted marketing, workflow management, store layout, and fraud detection. The lack of predicting the types of customer transactions made the managers and/or leaders of this coop finding difficulties in giving loans and accepting new coop members. The leaders also had problem in finding out the customers' profession who took loans the most from the coop. Thus, C4.5 algorithm was used to predict and discover the customer transactions [5].

A related study was undertaken by Putra (2015) who attempted to investigate the system of organoleptic test on tea leaves. The findings of the study showed that scoring system in processing the test was performed manually by using organoleptic test scoring sheets. This manual system was the common cause of document loss or document break. Therefore, new system to record the test results, namely mobile-based recording system on the Android platform was applied to resolve this problem [6].

Previous studies have demonstrated the organoleptic tests and invented Android application to assist the researchers in conducting online examination on the performed organoleptic test. Accordingly, by employing R\&D method, the present study makes several noteworthy contributions to the organoleptic test. Significantly, the present study seeks to create android product and implement decision tree algorithm to discover the hedonic scale of a food product.

\subsection{Organoleptic}

Organoleptic test consists of six stages which are receiving product, identifying product, clarifying the characteristics of the product, recalling the observed product, and restating the sensory nature of the product. These stages should be performed thoroughly since the test has strengths and weaknesses. Organoleptic test has high relevance on the quality of the product because it deals with direct contact with the consumers' preference. Furthermore, this method is quite easy and applicable. By conducting this test, the survey can be completed quickly and the result can be obtained easily. Weaknesses and limitations on the organoleptic test are caused by several sensory natures which cannot be explained. Sometimes, people who are selected as panelists affected by certain physical and mental conditions so that they become bored and their sensitivity decreases. This can lead to miscommunication between the manager and the panelists [7].

Organoleptic test refers to an evaluation by means of sensing process. Sensing could be defined as a physio-psychological process which explains about sensory awareness or the introduction to senses on the object traits. It occurs because of the stimuli received by the human senses. Due to this, the reaction or impression can be in form of an attitude to approach or to avoid, and like or dislike the stimuli. Under the circumstances, awareness, impression, and attitude towards stimuli are claimed as psychological or subjective reactions. Further, the scale measurement on those reactions is defined as a subjective measurement or subjective judgement because the result is determined by the examiners [8]. 


\section{$2.2 \quad$ C4.5 algorithm}

C4.5 algorithm is a part of decision tree algorithm group. This algorithm has an input in form of training samples and samples. Training samples are samples data which will be used to construct a tested and validity-proven tree. While samples are data fields that are used to be the parameter of the data classification process [9].

$\mathrm{C} 4.5$ algorithm is a method to create a decision tree from the provided training data. C4.5 algorithm is implemented by Ross Quinlan. This algorithm is the development of ID3 which was also created by Quinlan [9].

Furthermore, Quinlan developed C5.0 algorithm as the improved version of previous algorithms, namely ID3 and C4.5 algorithms. The main differences of C5.0 and C4.5 algorithms are [9]:

- C5.0 algorithm can handle continuous and discrete attributes

- The result of C5.0 decision tree can be simplified or pruned

- C5.0 algorithm requires less memory than the C4.5 version

- Compared to the C4.5 algorithm, the C5.0 requires less time on its speed

C4.5 algorithm has a more complex and extremely global area. It can be changed into simpler and more specific dataset by using an open source software, which is Waikato Environment for Knowledge Analysis (Weka), also known as J48.

\subsection{Decision tree}

The decision tree architecture is made in such a way to resemble the appearance of original tree. There are several parts in the tree, namely [10]:

- Root Node: The node is located on the top of the decision tree

- Internal Node: The branch node which requires one input and produces two outputs at its maximum result

- Leaf Node: The location of this node is on the tip of the tree. Leaf node only has an input, but do not have any output

Further, decision tree has several strengths and weaknesses, they are [10]:

\section{Decision tree strengths:}

a) The complex area of decision-making process can be converted into the simpler one.

b) Unnecessary calculation can be eliminated as the evaluation process is in line with the required criteria.

c) The features selection on the diverse internal nodes becomes more flexible. The selected features are the differentiator among the criteria.

d) Decision tree prevents problems to arise by using less amount of internal node without diminishing the quality of the final decisions. 
2. Decision tree weaknesses:

a) The possibility of overlapping the process if there is a huge amount of the final decisions and the applied criteria. Further, this makes the required time in making the decision and amount of memory increasing

b) The big amount of errors accumulation in each decision tree

c) The high level of difficulty in designing the decision tree

d) The high dependency on the design in claiming the decision quality

\subsection{C4.5 Algorithm equations and formula}

C4.5 is an algorithm which aims to support decision tree.

- The stages are as follows [11]:

- $\quad$ Select attributes as the roots

- Create branches for each value

- $\quad$ Divide the cases into the branches

- Repeat the process to each branch until the whole cases have the same classification

The entropy value calculation process are as follows:

$$
\operatorname{Entropy}(\mathrm{S})=\sum_{i=1}^{n}-p i * \log 2 \mathrm{pi}
$$

Description:

- S Case set

- A Feature

- $\mathrm{n}$ Number of S-partitions

- pi Proportion of Si to $S$

Selecting attributes as the roots requires the highest of gain calculation score from the existing attributes. The formula to calculate gain score is as follows:

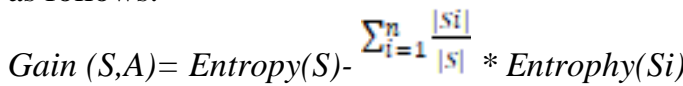

Description:

- S Case set

- A Attribute

- $n$ Number of A-partitions

- $\quad|\mathrm{Si}|$ Number of case on i-partitions

- $\quad|\mathrm{S}|$ Number of cases on $\mathrm{S}$

\section{$3 \quad$ Methodology}

Sugiyono (2009) asserts that R\&D research consists of 10 steps, namely:

1. Potential and problems

2. Information gathering

3. Product design 
4. Design validation

5. Design revision

6. Product trials

7. Product revision

8. Operation testing

9. Product revision

10. Mass production

Schematically, the steps above can be depicted through Figure 1.

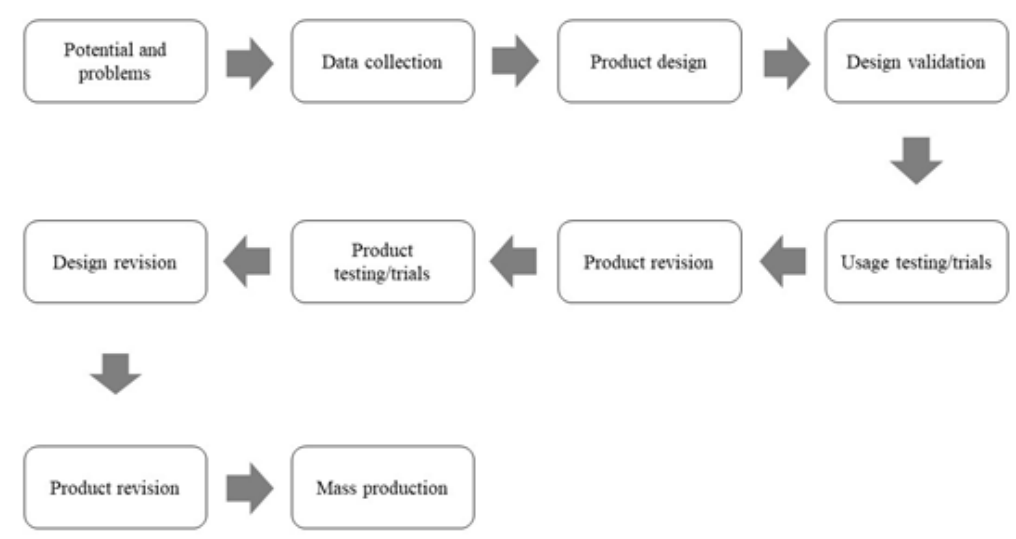

Fig. 1. R\&D Design [12]

The steps are briefly clarified through explanations below

Potential and Problems: A research is usually initiated after the presence of a specific potential or problem. Organoleptic test research faced problems such as the inaccurate manual calculation and limited research context consuming more time in collecting the data. Organoleptic test was conducted in multiple research context due to randomly-selected panelists. This research is intended to give insights for future food technology researches in Salatiga.

Information Gathering: The following step conducted by the researchers was collecting information and creating theoretical framework, which was used as the basis in planning a product making to solve the problems. On the other hand, the theoretical framework took roles in reviewing a specific product range, breadth of use, limitation, advantages, and supporting factors that make the product was optimally usable and implementable.

Table 1 depicts the suitability of hedonic rating scale or organoleptic test with the level of hedonic level. The number of hedonic scale might also vary due to desired quality range and scale gap sensitivity. The hedonic scale ranges from "good extreme" to "bad extreme", and the scale range. 
Table 1. Hedonic Rating Scale and Score [13]

\begin{tabular}{|c|c|}
\hline Hedonic Scale & Score \\
\hline Like extremely & 7 \\
\hline Like very much & 6 \\
\hline Like & 5 \\
\hline Dislike slightly & 4 \\
\hline Dislike moderately & 3 \\
\hline Dislike very much & 2 \\
\hline Dislike extremely & 1 \\
\hline
\end{tabular}

Product Design: In order to produce a brand-new work system, the product should be designed based on previous system assessment results. Therefore, the problems and errors were expected to be minimalized in the new product. $\mathrm{C} 4.5$ algorithm was used as the methodology in calculating the hedonic scale and the used Unified Modeling Language (UML) was Usecase Diagram and Class Diagram.

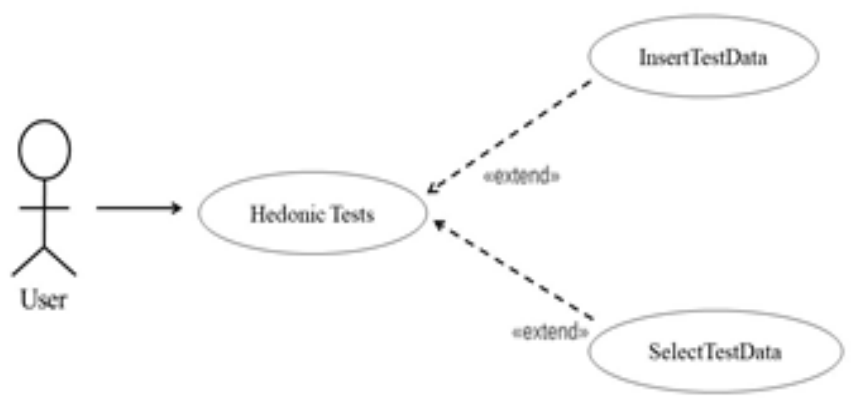

Fig. 2. Usecase Diagram

Figure 2 illustrates 1 actor (user) who designs this application. An actor has several access privileges, namely: inputting scores and monitoring data saved in the results.

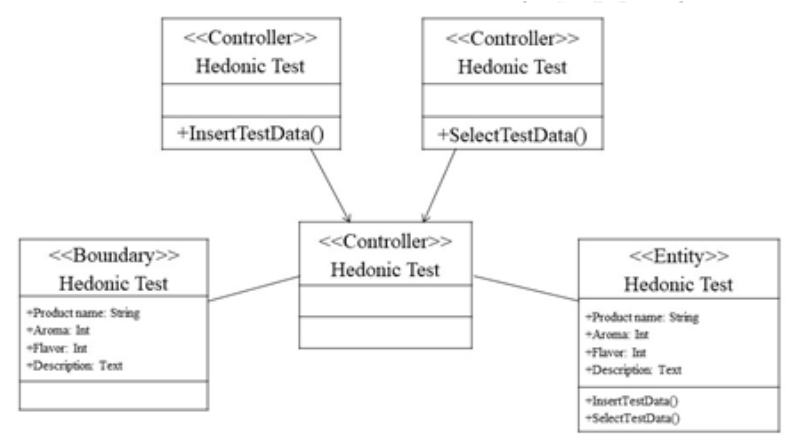

Fig. 3. Class Diagram 
In Figure 3, the relation of each class from hedonic test system is present. There was a set of boundary input which functions to fill the forms consisting of: hedonic scale, food product names, aroma, and flavors. Controller processed data from each activity done, while entity was a result table of the name of tested products, average total, and explanation.

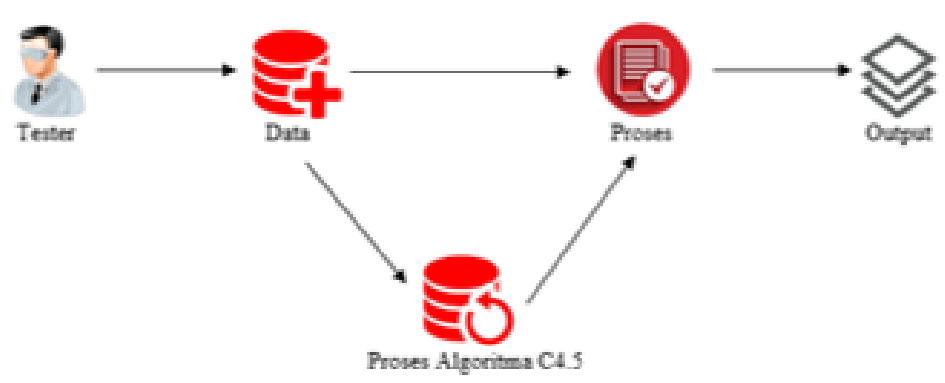

Fig. 4. System Architecture

Figure 4 shows the process of the system architecture. A tester applied the existing dataset and processed by $\mathrm{C} 4.5$ algorithm. The system worked, calculated, decided the dataset input, and gave the hedonic scale score of a food and beverage product as the output. The process was followed with algorithm development, from C4.5 algorithm to system examination. Some components such as problems, variables, and indicators must be applied in the calculation process. Each variable was determined and measured with $\mathrm{C} 4.5$ algorithm to generate a general conclusion. The following diagram shows the steps to develop the algorithm in the research:

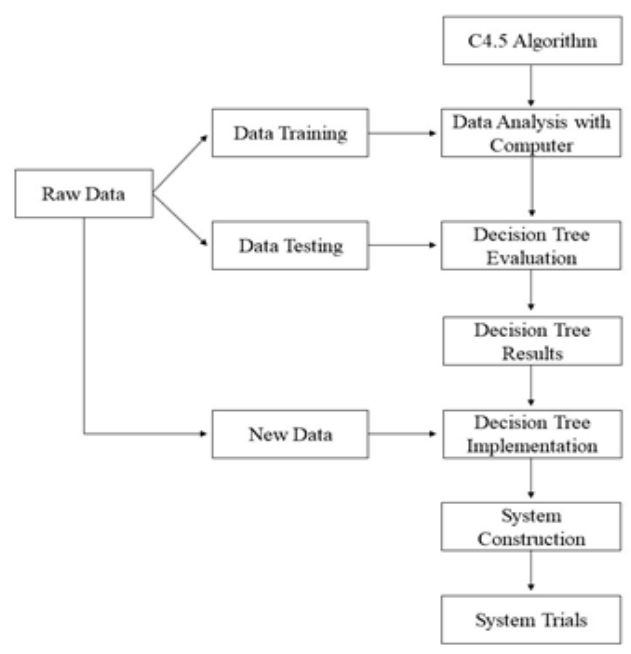

Fig. 5. Algorithm Development 
C4.5 Algorithm: The research utilized C4.5 algorithm to calculate the gain and entropy scores of the existing dataset, which the results later on were used to make a decision tree.

Data Analysis with Computer: This process was mainly analyzing the divided data into sub-components with the intention to deconstruct various problems and obstacles hindering the dataset.

Decision Tree Evaluation: The result of the decision tree was evaluated with data and information measurement, process, interpretation, and considerations to decide the result level of the decision tree.

Results and Decision Tree Implementation: The calculation results using C4.5 algorithm with decision tree methodology were later on applied and implemented into the system.

System Construction and Examination: Weka GUI Chooser was used to construct and examine the system. Weka is a Java-based data mining open source system which can be used in generalizing/formulating a group of calculated and concluded data.

Design Validation: Design validation is a process intended to evaluate a product design, in this case, rationally examining the effectiveness of a new work system compared to the previous one. The rate of this process was still "rationale" since the examination was till based on general knowledge instead of field findings. Thus, the system architecture was created to predict the plot of the planned system.

Design Revision: After designing the product, validated through discussions with experts, the "flaw" of the product was discovered. Then, the weaknesses were reduced by revising and repairing the product design. The researchers who are going to manufacture the product were in charge of the design revision process.

Product Trials: The product design could not be directly tested. Instead, the researchers must manufacture the product first. Later on, the manufactured product was tested with alpha test and beta test. Alpha test is a software examination strategy which is widely used in order to avoid defect and usage failure. On the other hand, beta test is a user test which is conducted directly and randomly to validate the function, compatibility, and reliability of the manufactured software.

Product Revision: Limited product sample testing might show a better work system performance compared with the previous ones, contrasting the manual calculation and calculation done with Android. Hence, the new work system could be applied and implemented.

Operation Testing: After the trials of the product met the set criteria, the sequence of step was followed by the product in form of the new work system was being applied and implemented in real context for a broader field. In the new work system operation, another examination was conducted to random respondents in order to conclude the usage trials/tests.

Product Revision: The product revision was conducted when the strengths and weaknesses of the new product were present in the real context examination. During the examination process, the application (Hedonic Test) was expected to function with low errors in automatic calculation. 
Mass Production: The final step of this research was to produce the application (Hedonic Test). The application was expected to work with zero errors. Hence, the application could be operated by researchers for organoleptic test (hedonic test) and/or the examination of preferences towards a food product within Salatiga and other cities.

\section{Discussion}

\subsection{The implementation of $\mathrm{C} 4.5$ algorithm calculation results}

Waikato Environment for Knowledge Analysis was employed for the calculation implementation with $\mathrm{J} 48$ classification methodology. The methodology is believed can be simply interpreted, helping the researchers in seeing the result of the decision tree from the analysis.

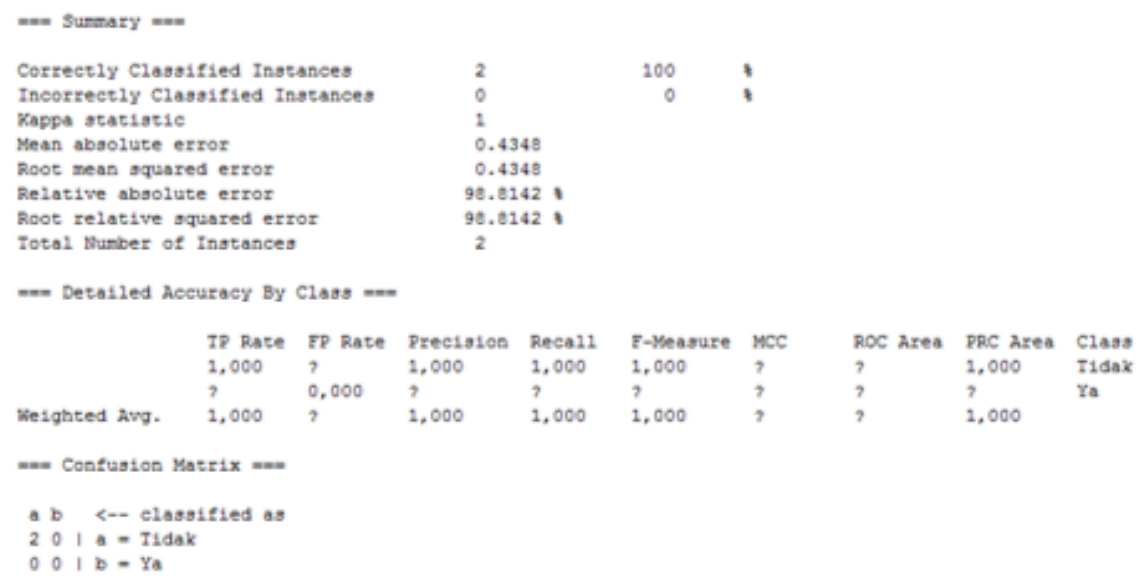

Fig. 6. Weka Calculation Results

Figure 6 showcases the Weka Classifier calculation results of the analysis, discovering correctly classified instances $100 \%$ and incorrectly classified instance $0 \%$ by applying $90 \%$ split. The node was formed by the attributes with lower gain score than the gain score of flavor attribute. This process was intended to attain gain score which has contrasting output, namely "yes" and "no", in the dataset by calculating the total of gain and entropy.

\subsection{The implementation on Weka and android}

The system testing was done with Waikato Environment for Knowledge Analysis (Weka) to minimize the errors within the new dataset. This test utilized a new dataset which was sorted into 50 data and calculated with Weka. Some of the retrieved dataset are mentioned below. 
Table 2. New Dataset

\begin{tabular}{|c|c|c|c|c|}
\hline No & Name & Aroma & Flavor & Hedonic Scale \\
\hline 1 & Febri & 1 & 1 & Dislike \\
\hline 2 & Doohan & 2 & 3 & Like slightly \\
\hline 3 & Huda & 1 & 2 & Neutral \\
\hline 4 & Faqih & 2 & 1 & Neutral \\
\hline 5 & Wardana & 3 & 3 & Like \\
\hline 6 & Dika & 3 & 4 & Like \\
\hline 7 & Indra & 4 & 3 & Like \\
\hline 8 & Willy & 4 & 4 & Neutral \\
\hline 9 & Amin & 1 & 3 & Like slightly \\
\hline 10 & Riska & 1 & 4 & \\
\hline
\end{tabular}

Table 2 depicts a new dataset with name, aroma, flavor, and hedonic scale as the attributes. The dataset was calculated and analyzed again with Weka to get new scores which was used in the next testing process

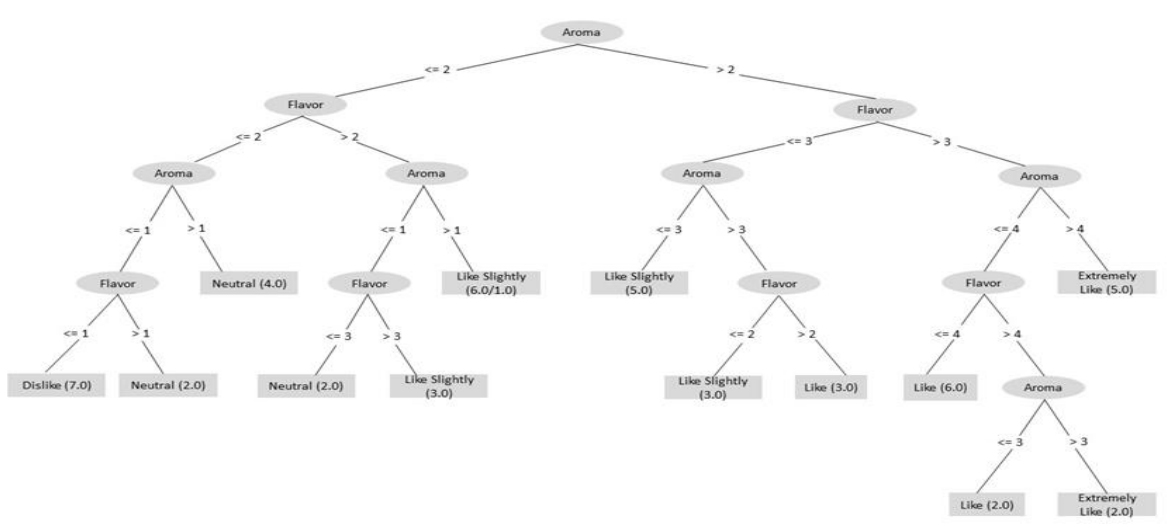

Fig. 7. Decision Tree Employing J48 Classification

Figure 7 displays how decision tree C4.5 algorithm stops forming new nodes if there were no further splitting paths. Each branch usually ended with "pure" leaf node, a node which targets quantification variable on every record in the node, to get same variable values for each equal aroma scores. However, there was a possibility that the node has various attributes, in which for each record with same aroma score has a different targeted variable value. This condition enabled further splitting paths for aroma scores. Therefore, the solution for this condition was to form leaf nodes with various leaf nodes by calculating the level of trust from the nodes' gap. After the tester was analyzed and recalculated, a new decision tree was formed to distinguish food products with decency to be consumed or to find out the results of food products organoleptic tests.

As has been noted that this research had built a system to identify the hedonic scale of a specific food and beverage products. This application was used by the employed panelists and randomly-picked panelists in the application. 


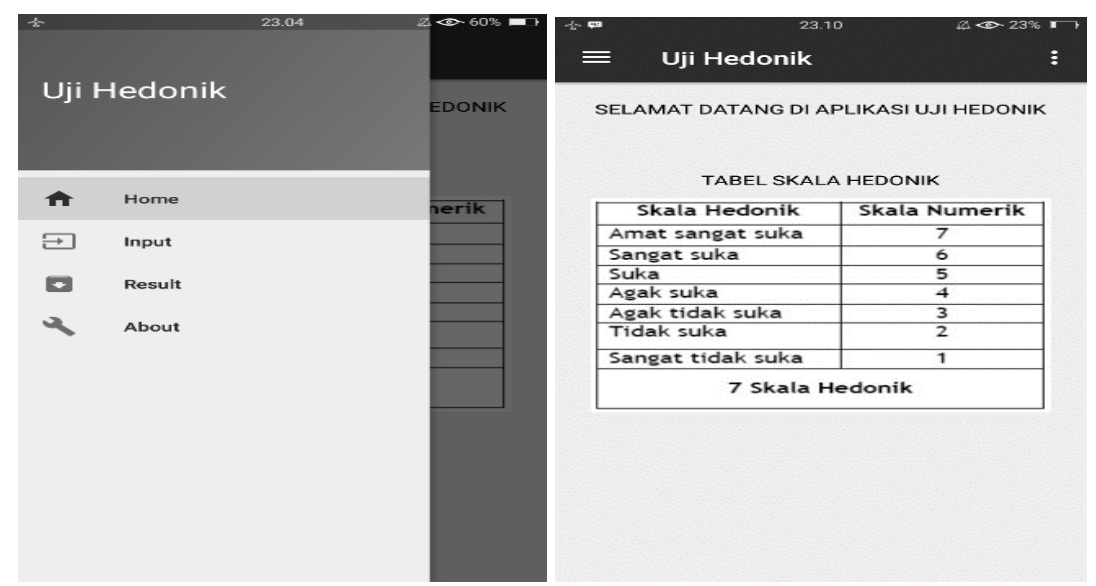

Fig. 8. The Front Display of Hedonic Test

In the Figure 8, it is displayed the front appearance of hedonic test application (home), consisting the scores of hedonic scale table from $1-7$. They are "like extremely", "like very much", "like", "like slightly", "dislike slightly", "dislike", and "dislike very much".

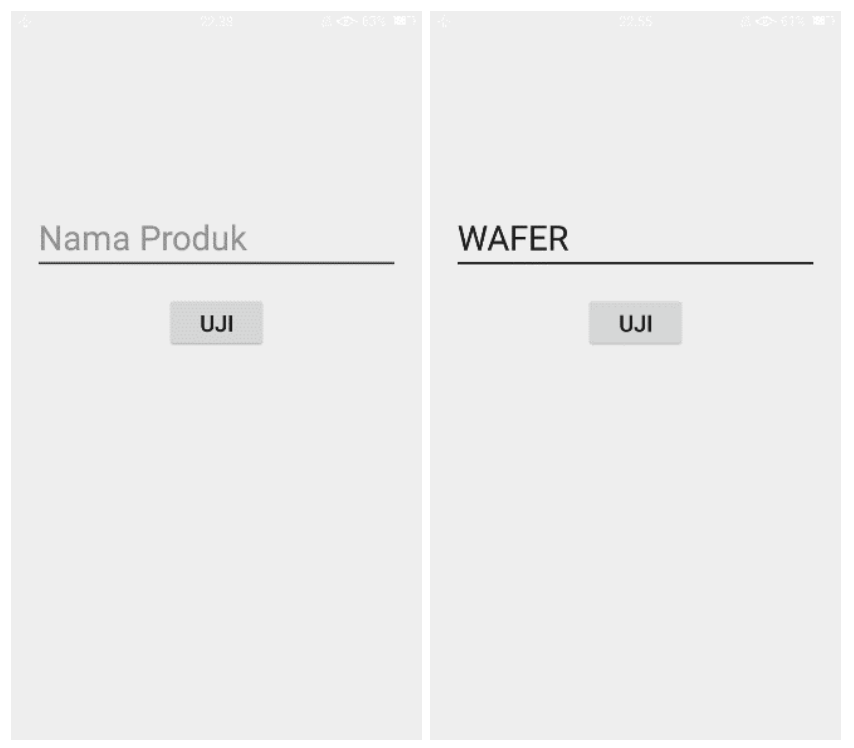

Fig. 9. The Display of Product Input

Figure 9 shows how the users run the organoleptic test application. Firstly, the users input the name of a food and/or beverage product they wanted to test. 


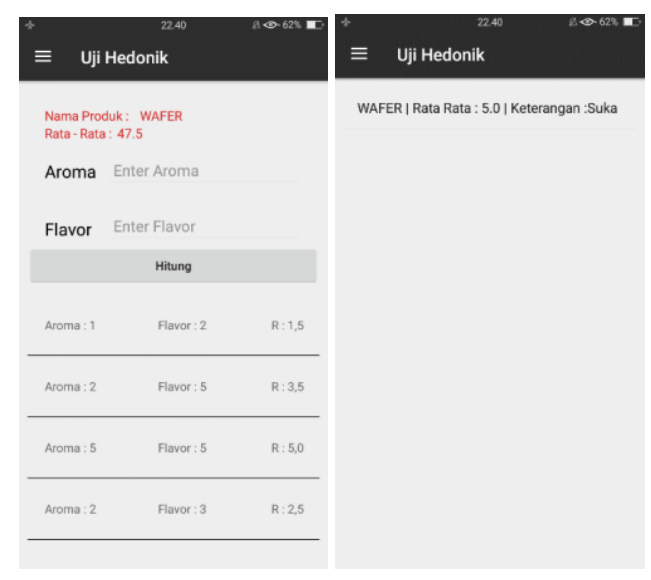

Fig. 10.The Display of Score Input

Figure 10 depicts the process of how aroma and flavor scores calculation generates hedonic scale score. The researchers were able to input aroma and flavor scores up to 15 times. Then, the add button turned into calculate button. The researchers proceed to the result of the calculation of the score that had been input 15 times. The calculation on the android system is demonstrated in Program Code 1.

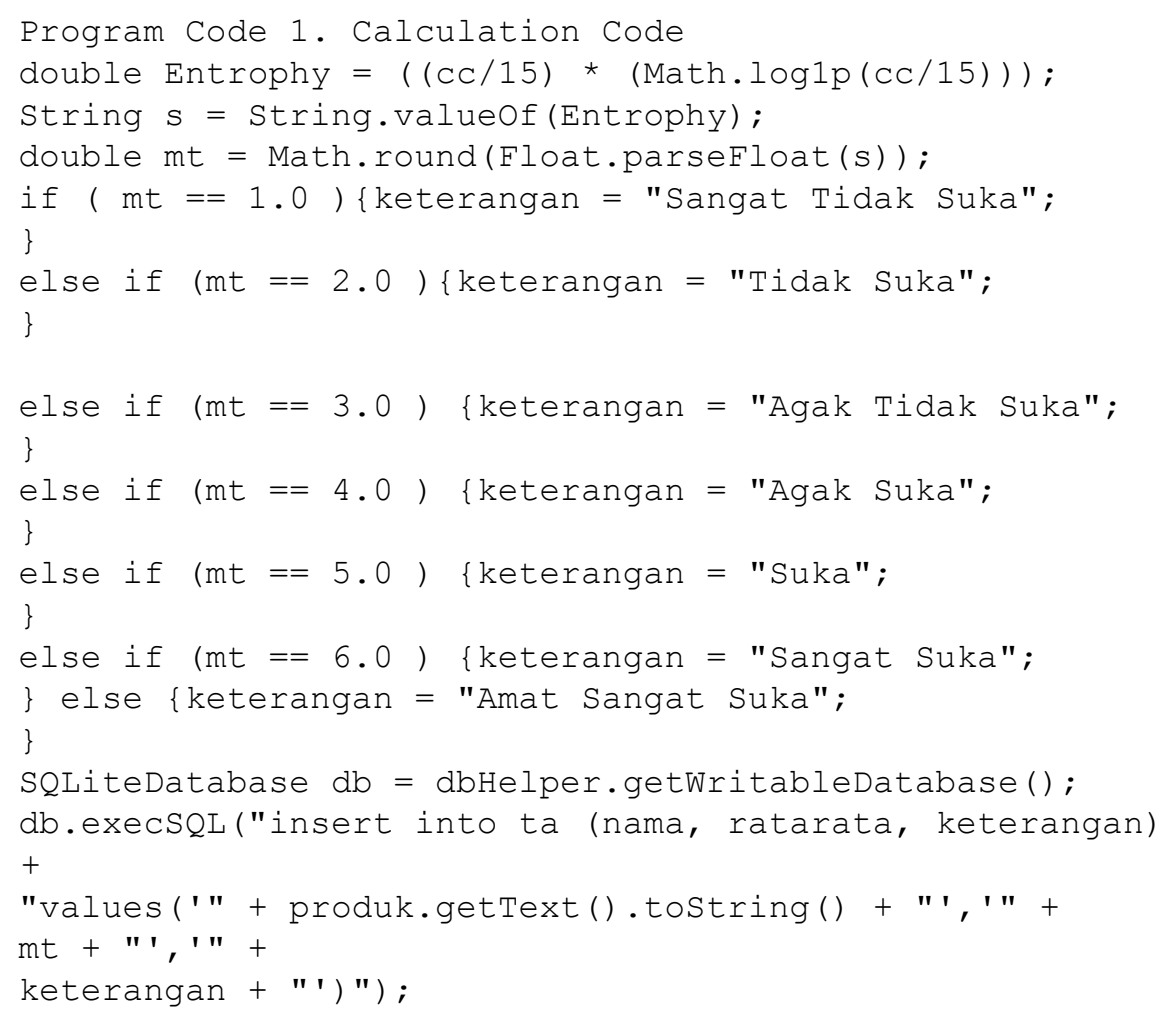


Program Code 1 explains that the first row is the formula to calculate the average amount beneath the product name. "Cc" is the total of average divided by 15 panelists who have completed the aroma and flavor attributes. Then, the calculation result was checked with "mt". If the result equals to 1 , the disclaimer will be "dislike extremely", equals to 2 "dislike", to equals to 7 "like extremely". After clicking the calculation button, the panelists were shown the result of the hedonic scale, which can be saved with SQLitedatabase. The next step was the process of system testing using alpha and beta test. Alpha testing is usually conducted by the application producers with the intention of identifying and intensively reducing the errors bugging the application.

\subsection{System trials}

Table 3. Application Trials

\begin{tabular}{|l|l|l|l|l|}
\hline Tested function & \multicolumn{1}{|c|}{ Condition } & Expected Output & \multicolumn{1}{|c|}{$\begin{array}{l}\text { Output Produced by The } \\
\text { System }\end{array}$} & Status \\
\hline $\begin{array}{l}\text { Product name } \\
\text { input }\end{array}$ & $\begin{array}{l}\text { The form is correctly } \\
\text { completed }\end{array}$ & $\begin{array}{l}\text { Successfully input the } \\
\text { name of the product }\end{array}$ & $\begin{array}{l}\text { Successfully input the name } \\
\text { of the product }\end{array}$ & Valid \\
\hline $\begin{array}{l}\text { Aroma value input } \\
(1-7)\end{array}$ & $\begin{array}{l}\text { The form is correctly } \\
\text { completed }\end{array}$ & $\begin{array}{l}\text { Successfully input the } \\
\text { aroma value }\end{array}$ & $\begin{array}{l}\text { Successfully input the aroma } \\
\text { value }\end{array}$ & Valid \\
\hline $\begin{array}{l}\text { Flavor value input } \\
(1-7)\end{array}$ & $\begin{array}{l}\text { The form is correctly } \\
\text { completed }\end{array}$ & $\begin{array}{l}\text { Successfully input the } \\
\text { flavor value }\end{array}$ & $\begin{array}{l}\text { Successfully input the flavor } \\
\text { value }\end{array}$ & Valid \\
\hline Data display & $\begin{array}{l}\text { Successfully displaying } \\
\text { the name of the product, } \\
\text { aroma value, flavour } \\
\text { value, and explanation }\end{array}$ & $\begin{array}{l}\text { Successfully displaying the } \\
\text { name of the product, aroma } \\
\text { value, flavour value, and } \\
\text { explanation }\end{array}$ & Valid \\
\hline
\end{tabular}

According to Table 3, it is shown that input function testing and data display are successful. This concludes that the application ran well and the expected function had been reached. Then, the process was entering the final step, beta testing. This test was conducted by those who did not participate in the application production process or expected users of this hedonic test application. The test was done by employing 30 arbitrary respondents to complete a set of questionnaires related to the application.

In this test, the participants were given 5 questions followed by 5 multiple choices, namely: SS=Extremely Agree, $\mathrm{S}=$ Agree, $\mathrm{R}=$ Not sure, $\mathrm{TS}=\mathrm{Disagree}$, and STS=Extremely Disagree. The survey was done with Likert scale to estimate expected users' opinions. The questionnaires were distributed to 30 participants arbitrarily and the respondents were expected to complete the questionnaires which were used to discover the level of the system decency created through this research.

The questionnaires consisted of 5 questions with each choice scoring 1 for "extremely disagree", 2 for "disagree", 3 for "not sure", 4 for "agree", and 5 for "extremely agree". After the questionnaires were completed, the scores were summed to see whether the created system is serviceable or not. Table 4 shows the retrieved scores from the questionnaires. 
Table 4. The Score of the Likert Scale

\begin{tabular}{|c|c|}
\hline Score & Explanation \\
\hline $0 \%-19,99 \%$ & Extremely disagree \\
\hline $20 \%-39,99 \%$ & Disagree \\
\hline $40 \%-59,99 \%$ & Not sure \\
\hline $60 \%-79,99 \%$ & Agree \\
\hline $80 \%-100 \%$ & Extremely agree \\
\hline
\end{tabular}

It is explained in the Table 4 that the survey results employing 30 respondents showed that majority of the respondents agreed that the application was qualified to be used. The first question obtained $76,67 \%$ for "agree" answer from the respondents, followed by $78 \%$ for second question, $76,67 \%$ for third question, $76 \%$ for fourth question, and $85,3 \%$ for the final question. The score retrieved from each question were calculated and divided by the number of questions to get the average score of the 5 questions. The system created purposively for this research got 78,53\% as the average score. Simultaneously, the hedonic test system retrieved "agree" assessment from the majority of the participants, concluding that the system was practical in organoleptic test and hedonic test process.

\section{Conclusion}

This research highlights the contribution of the application for the researchers in doing organoleptic test of a food product, which the results were examined with decision tree algorithm through hedonic scale scores and implemented in android mobiles. Frequently, decision tree algorithm classification or J48 in Weka 3.8.2 were able to classify data with above $90 \%$ accuracy. Simultaneously, the average of android speed performance reached $78,53 \%$. This demonstrates that the decision tree algorithm operated on android mobiles had reliable performance in classifying the data.

\section{References}

[1] Ayustaningwarno F., 2014, "Teknologi Pangan; Teori Praktis dan Aplikasi”, Graha Ilmu, Yogyakarta.

[2] Slamet, A.,2007, "Manajemen Sumber Daya Manusia", Universitas Negeri Semarang, Semarang.

[3] Sartika, D. dan Sensure, I. D., 2017, "Perbandingan Algoritma_Klasifikasi Naive Bayes, Nearest Neighbour, dan Decision Tree pada Studi Kasus Pengambilan Keputusan Pemilihan Pola Pakaian", Jatisi, Vol. 1 No. 2 https://doi.org/10.30998/string.v1i1.968

[4] Tarwendah P. Ivani, 2017, "Studi Komparasi Atribut Sensoris dan Kesadaran Merek Produk Pangan", Jurnal Pangan dan Agroindustri Vol. 5 No. 2: 66-73

[5] Widayu Hikma, 2017,'Data Mining untuk Memprediksi Jenis Transaksi Nasabah pada Koperasi Simpan Pinjam dengan Algoritma C4.5”, Media Informatika Budidarma, Vol. 1 No. 2 https://doi.org/10.26877/jiu.v4i2.2919 
[6] Putra Steven Sophian, 2015,"Perancangan dan Implementasi Sistem Pencatatan Hasil Uji Organoleptik di PT. Gunung Slamat pada Android Platform", Universitas Kristen Satya Wacana: Institutional Repository. https://doi.org/10.28932/jutisi.v1i3.391

[7] Nasiru, B., F., Muhammad, Z., 2001, "Effect Cooking Time and Potash Contretaction on Organic Properties of Red and White Meat", Journal of Food Technology 9 (4): 119-123

[8] Soekarto. 1990. "Penilaian Organoleptik Untuk Industri Pangan dan Hasil Pertanian". Jakarta: Bhatara Aksara.

[9] Quinlan, J., R., 1993,’C4.5: Programs for Machine Learning”, Morgan Kaufman Publishers

[10] Sunjana, 2010, Seminar Nasional Aplikasi Teknologi Informasi 2010, “Aplikasi Mining Data Mahasiswa Dengan Metode Klasifikasi Decision Tree", 4-29 https://doi.org/10.22 146/jnteti.v8i2.506

[11] Kusrini., Luthfi T., E., 2009,"Algoritma Data Mining”, Andi Offset, Yogyakarta

[12] Sugiyono. 2009. Metode Penelitian Pendidikan Pendekatan Kuantitatif, Kualitatif, dan R\&D. Bandung: Alfabeta.

[13] Rahayu, W.P. 1998, "Diktat Penuntun Praktikum Penilaian Organoleptik", Fakultas Teknologi Pertanian Bogor, Institut Pertanian Bogor. https://doi.org/10.6066/jtip.2016. $\underline{27.1 .31}$

\section{Authors}

Radius Tanone is Lecturer at Faculty of Information Technology, Satya Wacana Christian University. He is currently involved in research related to software engineering, Artificial Intelligence and mobile computing.

Hendra Budi Prasetya is Bachelor from Faculty of Information Technology, Satya Wacana Christian University. He is an android programmer and doing some jobs in application development.

Article submitted 2018-10-08. Resubmitted 2019-06- 16. Final acceptance 2019-06-16. Final version published as submitted by the authors. 